\title{
Calcium and magnesium biogeochemistry in spruce catchments underlain by felsic, mafic, and ultramafic rocks
}

\author{
Pavel Krám ${ }^{1,2, *}$, Filip Oulehle ${ }^{1,2}$, Jakub Hruška ${ }^{1,2}$, František Veselovský1 ${ }^{1}$, Jan Cuřrik ${ }^{1,2}$, \\ Oldřich Myška ${ }^{1,2}$, Martin Novák ${ }^{1}$, and William $H$. McDowell ${ }^{3}$ \\ ${ }^{1}$ Czech Geological Survey, Klárov 3, 11821 Prague 1, Czech Republic \\ ${ }^{2}$ Global Change Research Institute, Czech Academy of Sciences, Bělidla 4a, Brno, Czech Republic \\ ${ }^{3}$ University of New Hampshire, Dept. of Nat. Resour. and the Environ., Durham, NH 03824, USA
}

\begin{abstract}
Three small forested catchments in the Czech Republic, each underlain by chemically contrasting silicate rocks, were investigated with focus on long-term atmospheric deposition of $\mathrm{S}$, and pools and fluxes of $\mathrm{Ca}$ and $\mathrm{Mg}$. Pools of $\mathrm{Ca}$ and $\mathrm{Mg}$ reflected geological substrate (granite: $\mathrm{Ca}$, $\mathrm{Mg}$ poor, amphibolite: $\mathrm{Ca}, \mathrm{Mg}$ rich, serpentinite: $\mathrm{Ca}$ poor, $\mathrm{Mg}$ rich). Longterm fluxes of $\mathrm{S}, \mathrm{Ca}$ and $\mathrm{Mg}$ were tightly connected.
\end{abstract}

\section{Introduction}

Biogeochemical cycling of divalent base cations (calcium and magnesium, $\mathrm{Ca}$ and $\mathrm{Mg}$ ) is important for the environmental status of forest ecosystem as $\mathrm{Ca}$ [1] and $\mathrm{Mg}$ [2] are essential nutrients for tree growth. Atmospheric deposition [3] and chemical weathering [4] are the principal sources of dissolved $\mathrm{Ca}$ and $\mathrm{Mg}$, and these ecosystem inputs are critical in regulating the acid-base status of soils and drainage waters [1].

\section{Study area and methods}

Study catchments are located 5-7 km apart in a mountainous region of the Slavkov Forest (Slavkovský les) in western Bohemia, Czech Republic. They have similar area and altitude (Tab. 1), annual mean air temperature $\left(5-6^{\circ} \mathrm{C}\right)$, atmospheric deposition and forest cover (mainly even-aged plantations of Norway spruce (Picea abies)). However, they have chemically different bedrock and soil (Tab. 1). The catchments belong to the Czech GEOMON network [5]. The Lysina catchment (LYS) is regularly monitored as part of several international networks, e.g. ICP Integrated Monitoring [6].

Complete integrated monitoring of atmospheric deposition inputs and stream water outputs started in 1991 at LYS, in 1992 in the Pluhův Bor (PLB) catchment, and in 2015 in the Na Zeleném (NAZ) catchment. Bulk precipitation was collected monthly by 2 collectors at each catchment. Canopy throughfall was collected by 10 collectors at LYS and PLB and by 5 collectors at NAZ. Stream water discharge was monitored using V-notch weirs and

* Corresponding author: pavel.kram@geology.cz 
water level recorders. Stream water was collected weekly at LYS and PLB, and monthly at NAZ. Rocks were sampled from three boreholes drilled in 2012. Soils were sampled in summer of 2015 based on 17 quantitative $0.5 \mathrm{~m}^{2}$ soil pits [7] with separate samples of organic soil and samples of mineral soil in 0-10, 10-20, 20-40 and 40-80 cm intervals. Bole wood was sampled by an increment borer from nine trees in summer 2010 (LYS, PLB) and fall 2010 (NAZ). Spruce needles were obtained from 51 trees in early fall of 2015. Soil analyses were conducted using air dried samples of the fine fractions $(<5 \mathrm{~mm}$ for organic soil and $<2 \mathrm{~mm}$ for mineral soils). Soil exchangeable base cations were leached by $0.1 \mathrm{M}$ $\mathrm{BaCl}_{2}$. Base saturation was determined as the fraction of cation exchange capacity associated with base cations. Water analyses were performed by standard methods in the Accredited Laboratory of the CGS. Concentrations of base cations were determined by atomic absorption (FAAS) and $\mathrm{pH}$ with a combination electrode. Tree biomass pools were calculated for 17 tree plots each with $500 \mathrm{~m}^{2}$ area and recalculated for the whole catchment area using national orthophotos and detailed official forest stand maps and forest management inventories. Annual elemental fluxes were calculated using monthly concentrations and monhly water fluxes for bulk precipitation and throughfall; and annual discharge-weighted mean solute concentrations and annual water flux were used to calculate stream export.

\section{Results and discussion}

The LYS catchment had almost complete canopy cover of Norway spruce, with $<0.5 \%$ of European beech (Fagus sylvatica). Closed canopy forest at NAZ was formed mainly by spruce $(97 \%)$, with small amounts of deciduous trees (3\%), especially beech and speckled alder (Alnus incana). PLB experienced periodic cutting of stands in a rotation in the last decade but was completely forested prior to the cutting. Therefore the present coverage of closed tree canopy forest at PLB is the smallest (Tab. 1). Spruce plantations were dominant also at PLB, with minor (14\%) admixed coverage of Scots pine (Pinus sylvestris).

Soils at LYS were very acidic (pH in distilled water 3.4 for organic soil and 3.7 for upper $10 \mathrm{~cm}$ of mineral soil), with both lumped soil $\mathrm{pH}$ values around 4; Tab. 1). Soil $\mathrm{pH}$ increased with depth at PLB to near-neutral values (mineral soil $40-80 \mathrm{~cm} \mathrm{pH}_{\mathrm{H} 2 \mathrm{O}} 6.6$ ), with lumped mean soil $\mathrm{pH}$ 5.9. NAZ exhibited intermediate $\mathrm{pH}$ values (Tab. 1). Base saturation (BS) was markedly different at the three sites. PLB exhibited very high BS (Tab. 1), up to $98 \%$ in the deepest soil layers and was caused almost exlusively by exchangeable $\mathrm{Mg}$. NAZ exhibited high BS, generated mostly by exchangeable Ca. In contrast, LYS showed very low lumped BS of $7 \%$, with the mineral soil BS in the layer of $20-80 \mathrm{~cm}$ of only $6 \%$.

Table 1. Characteristics of the study catchments. Soil chemistry represents the lumped organic soil horizon and upper $80 \mathrm{~cm}$ of mineral soil. $\mathrm{BS}=$ base saturation, soil $\mathrm{pH}$ was measured in distilled water and $0.1 \mathrm{M} \mathrm{KCl}$.

\begin{tabular}{|c|c|c|c|c|c|c|c|c|}
\hline Site & $\begin{array}{c}\text { Area } \\
\text { (ha) }\end{array}$ & $\begin{array}{c}\text { Altitude } \\
\text { (m a.s.l.) }\end{array}$ & $\begin{array}{c}\text { Prevailing } \\
\text { rock }\end{array}$ & $\begin{array}{c}\text { Prevailing } \\
\text { soil }\end{array}$ & $\begin{array}{c}\text { Soil } \\
\text { BS } \\
\mathbf{( \% )}\end{array}$ & \multicolumn{2}{|c|}{$\begin{array}{c}\text { Soil pH } \\
(\mathbf{H} \text { (2) } \\
(\mathbf{K C l})\end{array}$} & $\begin{array}{c}\text { Closed tree } \\
\text { canopy (\%) }\end{array}$ \\
\hline LYS & 27.3 & $829-949$ & Granite & Podzol & 7 & 4.3 & 3.8 & 99 \\
\hline NAZ & 55.0 & $736-802$ & Amphibolite & Cambisol & 53 & 5.1 & 3.9 & 88 \\
\hline PLB & 21.6 & $690-804$ & Serpentinite & Stagnosol & 86 & 5.9 & 4.6 & 81 \\
\hline
\end{tabular}


Peak values of sulfur (S) emissions were recorded in the middle of 1980 [3] in central Europe, before our monitoring started. Atmospheric deposition of S at LYS exhibited a sharp decline in the 1990s (Fig. 1) mainly due to massive deployment of desulfurization equipment between 1993-1999 in North Bohemian brown coal-burning power plants situated 12-70 km northwest to northeast [8]. Smaller decline of S deposition was detected afterwards. Such a large decline of S deposition due to decreased industrial emissions could be compared only to several industrial regions in the World, like around Sudbury, Ontario, Canada [9] or around Monchegorsk and Nikel, Kola, Russia [10] and has not been described in western Europe [11].

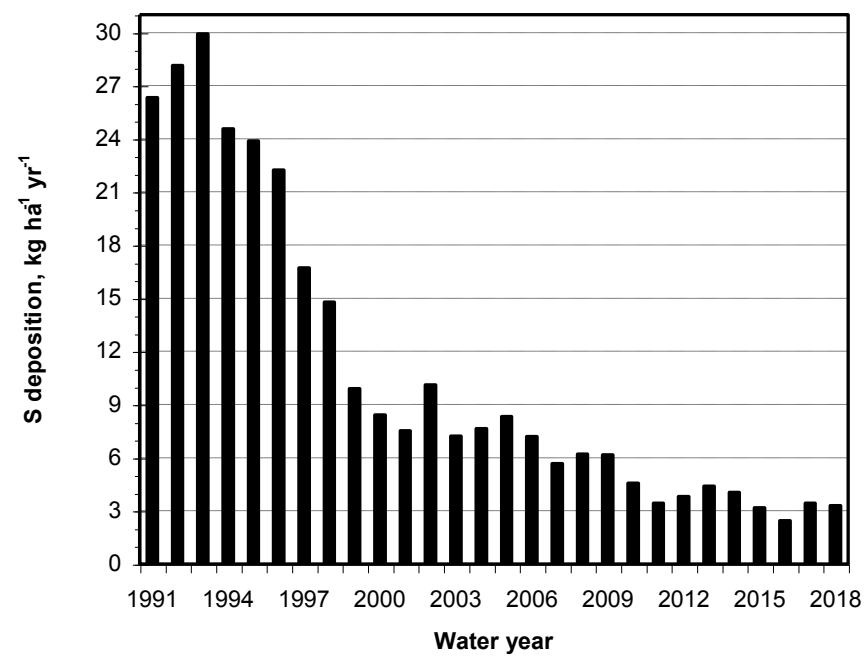

Fig. 1. Annual fluxes of atmospheric deposition of sulfur in the forested Lysina catchment in 19912018 water years, based on canopy throughfall measurements.

Acid-base chemistry of drainage waters is mainly influenced by atmospheric deposition of acidifying compounds and by the geochemical reactivity of the underlying bedrock. The extent to which chemical weathering and soil equilibrium reactions can protect against anthropogenic acidification is largely influenced by availability and supply of Ca and $\mathrm{Mg}$.

Pools of $\mathrm{Ca}$ and $\mathrm{Mg}$ in selected catchment compartments at LYS, NAZ and PLB were calculated (Tab. 2). Total pools of $\mathrm{Ca}$ and $\mathrm{Mg}$ in just one meter of underlying bedrock are usually three orders of magnitude larger than soil exchangeable pools. The only exception was Ca at PLB because serpentinite sampled in the upper part of the borehole exhibited an extremely low concentration of $\mathrm{Ca}$, which is typical of serpentinite. However, deeper parts of the borehole detected other ultramafic and mafic rocks all with much higher concentations of $\mathrm{Ca}[12,13]$. Also previous investigations [14] discovered that only about half of catchment outcrops at PLB were formed by serpentinite, others contained e.g. tremolite schist which contains similarly high amounts of Ca like amphibolite. Very small bedrock pools of $\mathrm{Mg}$ at LYS reflect consistently its mineralogical composition [15]. As a consequence Mg pools in trees at LYS, especially in spruce needles were very low (Tab. 2). Spruce needles at LYS exhibited classical symptoms of Mg deficiency [16, 17]. Spruce at NAZ did not exhibit any symptoms of deficiency, hower spruce at PLB suffered by deficiency of other nutrients such as K and especially P [17]. 
Table 2. Pools of $\mathrm{Ca}$ and $\mathrm{Mg}$ in different compartments at three study catchments. Spruce and rock results are based on total concentrations; soil results are based on exchangeable concentrations. The rock pools are based on the borehole core samples from 4-5 m below the surface.

\begin{tabular}{|c|c|c|c|c|c|c|}
\hline \multirow[b]{2}{*}{ Compartment (thickness) } & \multicolumn{3}{|c|}{ Calcium $\left(\mathrm{kg} \mathrm{ha}^{-1}\right)$} & \multicolumn{3}{|c|}{ Magnesium (kg ha-1) } \\
\hline & LYS & NAZ & PLB & LYS & NAZ & PLB \\
\hline Spruce needles & 52 & 65 & 37 & 11 & 106 & 136 \\
\hline Spruce bole wood & 125 & 133 & 136 & 14 & 30 & 43 \\
\hline $\begin{array}{c}\text { Organic soil } \\
(8 \mathrm{~cm} \text { at LYS, } 4 \mathrm{~cm} \text { at NAZ, } \\
\text { and } 7 \mathrm{~cm} \text { at PLB })\end{array}$ & 48 & 98 & 143 & 7 & 22 & 296 \\
\hline Mineral soil $(80 \mathrm{~cm})$ & 229 & 3720 & 695 & 57 & 1350 & 5120 \\
\hline Rock (100 cm) & $9.710^{4}$ & $1.810^{6}$ & $7.310^{3}$ & $3.010^{4}$ & $1.910^{6}$ & $5.810^{6}$ \\
\hline
\end{tabular}

Fluxes of $\mathrm{Ca}$ and $\mathrm{Mg}$ in bulk precipitation, canopy throughfall and surface runoff in three time periods at the study catchments are shown in Tab. 3. The first short period [18] represents the situation only several years after the peak deposition of S [3]. It exhibited slightly larger precipitation fluxes in comparison to the later periods and much larger fluxes (especially $\mathrm{Ca}$ ) in throughfall due to the higher contribution of dry deposition and canopy leaching. Also runoff fluxes in the first period exhibited much larger values. The long middle period evaluated statistically in [5] shows mostly intermediate fluxes at LYS, with the exception of $\mathrm{Mg}$ in precipitation. Evaluation of long-term trends at PLB showed inconsistent results. Most of the trends from 1994-2014 at PLB were not statistically significant, the only exceptions were decline in precipitation fluxes by $0.07 \mathrm{~kg} \mathrm{Ca} \mathrm{ha}^{-1} \mathrm{yr}^{-1}$ and in throughfall fluxes by $0.24 \mathrm{~kg} \mathrm{Ca} \mathrm{ha}^{-1} \mathrm{yr}^{-1}$. On the contrary almost all the long-term trends at LYS were statistically significant. All changes at LYS also exhibited decline, the same as at PLB for Ca in precipitation. Declines of throughfall fluxes were $0.42 \mathrm{~kg} \mathrm{Ca} \mathrm{ha}^{-1}$ $\mathrm{yr}^{-1}$ and $0.05 \mathrm{~kg} \mathrm{Mg} \mathrm{ha}^{-1} \mathrm{yr}^{-1}$ and declines of runoff fluxes were $0.56 \mathrm{~kg} \mathrm{Ca} \mathrm{ha}^{-1} \mathrm{yr}^{-1}$ and 0.09 $\mathrm{kg} \mathrm{Mg} \mathrm{ha} \mathrm{yr}^{-1} \mathrm{yr}^{-1}$ aYS. Throughfall fluxes from the last period covering for the first time all three investigated catchments exhibited signs of internal cycling at catchments with rich geological substrate with respect to some nutrient elements. Throughfall fluxes of $\mathrm{Mg}$ at PLB were 2.2 times or 4.8 times larger than at NAZ or LYS, respectively. Similarly the largest throughfall fluxes of $\mathrm{Ca}$ were documented at NAZ. Influence of the substrate was much more obvious for runoff with $\mathrm{Ca}$ fluxes about three times larger at NAZ in comparison to LYS and PLB. Differences in runoff fluxes of Mg were stunning, with $\mathrm{Mg}$ export at PLB 37 times larger than at LYS and 6 times larger than at NAZ. The large decline of sulfate (the major mobile anion) in drainage water [11] was generated by a dramatic decline in deposition of S (Fig. 1). Declining stream water fluxes of $\mathrm{Ca}$ and $\mathrm{Mg}$ at acidified LYS (Tab. 3) mimic this trend lowering losses of these cations from soil exchange sites. Our ongoing isotopic project $\left({ }^{44} \mathrm{Ca},{ }^{26} \mathrm{Mg}\right)$ should help to better understand pecularities of weathering, internal cycling, dry deposition and other processes. 
Table 3. Fluxes of $\mathrm{Ca}$ and $\mathrm{Mg}$ at the study catchments. Data from [5] show annual means and standard deviations (the underlined data show corresponding statistically significant linear regression trends of decline at $\alpha=0.05$, values discussed in the text).

\begin{tabular}{|c|c|c|c|c|c|c|}
\hline & \multicolumn{3}{|c|}{ Calcium (kg ha-1 $\left.\mathbf{y r}^{-1}\right)$} & \multicolumn{2}{c|}{ Magnesium (kg ha-1 $\left.\mathbf{y r}^{-1}\right)$} \\
\hline Compartment (water years) & LYS & NAZ & PLB & LYS & NAZ & PLB \\
\hline Precipitation (1992-1993)[18] & 3.1 & - & - & 0.6 & - & - \\
\hline Precipitation (1994-2014)[5] & $\underline{2.2 \pm 1.0}$ & - & $\underline{2.0 \pm 0.7}$ & $0.4 \pm 0.1$ & - & $0.5 \pm 0.2$ \\
\hline Precipitation (2015-2017) & $\mathbf{2 . 0}$ & $\mathbf{1 . 6}$ & $\mathbf{1 . 5}$ & $\mathbf{0 . 4}$ & $\mathbf{0 . 4}$ & $\mathbf{0 . 4}$ \\
\hline Throughfall (1992-1993)[18] & 12.1 & - & 8.8 & 2.2 & - & 5.3 \\
\hline Throughfall (1994-2014)]5] & $\underline{6.6 \pm 3.0}$ & - & $\underline{4.6 \pm 2.0}$ & $\underline{1.3 \pm 0.4}$ & - & $3.9 \pm 1.1$ \\
\hline Throughfall (2015-2017) & $\mathbf{3 . 2}$ & $\mathbf{5 . 5}$ & $\mathbf{4 . 9}$ & $\mathbf{0 . 9}$ & $\mathbf{2 . 0}$ & $\mathbf{4 . 3}$ \\
\hline Runoff(1992-1993)[18] & 15.5 & - & 4.1 & 3.0 & - & 38.7 \\
\hline Runoff(1994-2014)[5] & $\underline{8.4 \pm 4.4}$ & - & $4.2 \pm 1.0$ & $\underline{1.8 \pm 1.2}$ & - & $40.5 \pm 9.4$ \\
\hline Runoff (2015-2017) & $\mathbf{3 . 3}$ & $\mathbf{1 0 . 0}$ & $\mathbf{3 . 0}$ & $\mathbf{0 . 8}$ & $\mathbf{5 . 0}$ & $\mathbf{2 9 . 6}$ \\
\hline
\end{tabular}

This paper was supported by the Czech Science Foundation grants 18-15498S (MN), 18-17295S (JH) and 16-15498S (F. Moldan), and internal projects of the Czech Geological Survey 310010 (PK) and 331900 (FO), and the US National Science Foundation EAR 13-31841 (WHM). Technical help of V.Kmínek, J. Václavek, V. Chlupáčková, L. Bohdálková and T. Chuman is acknowledged.

\section{References}

1. G.E. Likens, C.T. Driscoll, D.C. Buso et al., Biogeoch. 41, 89-173 (1998)

2. R. Hüttl, W. Schaaf (eds.), Magnesium deficiency in forest ecosystems (Kluwer, 1997)

3. J. Kopáček, J. Hejzlar, P. Krám, F. Oulehle, M. Posch, Water Res. 103, 30-37 (2016)

4. N. Dannhaus, H. Wittmann, P. Krám et al., Geoch. Cosm. Acta 222, 618-641 (2018)

5. F. Oulehle, T. Chuman, J. Hruška et al., Biogeoch. 132, 251-272 (2017)

6. J. Vuorenmaa, A. Augustaitis, B. Beudert et al., Sci. Tot. Environ. 625, 1129-45 (2018)

7. T.G. Huntington, D.F. Ryan, S.P. Hamburg, Soil Sci. Soc. Am. J. 52, 1162-1167 (1988)

8. V. Majer, P. Krám, J.B. Shanley, Envir. Pollut. 135, 17-28 (2005)

9. W. Keller, N.D. Yan, J.M. Gunn et al., Water Air Soil Poll. Focus 7, 317-322 (2007)

10. N.A. Gashkina, T.I. Moiseenko, Doklady Earth Sci. 476, 1073-1079 (2017)

11. R.C. Helliwell, R.F. Wright et al., Env. Sci. Technol. 48, 13280-13288 (2014)

12. V. Štědrá, P. Krám, J. Farkaš, Geosci. Res. Rep. for 2014, 103-108 (2015)

13. P. Krám, J. Čuř́k, F. Veselovský et al., Proc. Earth Planet. Sci. 17, 538-741 (2017)

14. P. Krám, F. Oulehle, V. Štědrá et al., Northeast. Natural. 16, Spec. 5, 309-328 (2009)

15. V. Štědrá, T. Jarchovský, P. Krám, Geosci. Res. Rep. 49, 137-142 (2016)

16. J. Hofmeister, F. Oulehle, P. Krám, J. Hruška, Biogeoch. 88, 139-151 (2008)

17. N.P. Rosenstock, C. Berner, M.M. Smits et al., New Phytol. 211, 542-553 (2017) 
18. P. Krám, J. Hruška, B.S. Wenner, C.T. Driscoll et al., Biogeoch. 37, 173-202 (1997) 